\title{
DINAMISASI PESANTREN PERSPEKTIF KHAS DALAM KONSTRUKSI MAJALAH PESANTREN TAHUN 1985
}

\author{
Kun Wazis \\ Pascasarjana IAIN Jember \\ kunwazis@gmail.com
}

\begin{abstract}
The perspective of a Kyai (a Javanese expert in Islam) in critically perceiving Islamic scholars becomes an important discourse in the changing face of Pesantren (Islamic boarding schools) from time to time. KyaiHaji Ahmad Shiddiq (KHAS) was one of the most notable figures who had extensive experiences in establishing this classical Islamic institution specific to Indonesia. In order to accentuate the great services of the late Jember figure, the State Islamic Institute of Jember (IAIN Jember) proposed the name KHAS as the new identity for the proposed institutional change status to become State Islamic University (UIN). This study attempted to explain KHAS' perspective on Ulama (Islamic scholars) and Pesantren whose original thoughts were written in Pesantren Magazine in 1985. Employing a qualitative approach, focusing on text analysis of KHAS' articles, an overview was obtained about the credibility of Ulama, the identity of Kyai, and the dynamics of Pesantren in Indonesia at that time and in the future to come. The results of the current study confirmed three important things. First, Ulama inherit the leadership roles of the Prophet Muhammad PBUH in terms of knowledge, deed, and morality. Second, the identity of a Kyai is presented to individuals who have reached the level of Ulama. Third, the dynamics of Pesantren community are carried out with two types of improvement, namely recovery and development.
\end{abstract}

Keywords: Pesantren dynamics, KHAS' perspectives, Pesantren magazines

\section{Pendahuluan}

LangkahInstitut Agama Islam Negeri Jember (IAIN Jember) untuk merubah status perguruan tinggi menjadi Universitas Islam Negeri (UIN) Kyai Haji Ahmad Shiddiq (KHAS) ${ }^{1}$ menjadi isu menarik untuk dilihat dari

1Sejumlah media massa, terutama online, memberitakan upaya IAIN Jember berubah status menjadi UIN Jember. Periksa https://beritajatim.com/pendidikankesehatan/iain-jember-bertransformasi-jadi-uin-kh-achmad-shiddiq/, diakses 22 
beragam sudut pandang. Pertama, posisi IAIN Jember sebagai satu-satunya Perguruan Tinggi Keagamaan Islam Negeri (PTKIN) yang berada di Jawa Timur bagian Timur yang meliputi wilayah Banyuwangi, Situbondo, Bondowoso, Jember, Lumajang, Probolinggo, dan Pasuruan. Jika beralih status, maka akan memberikan dampak besar dalam dinamika kehidupan pendidikan tinggi di kawasan Tapal Kuda tersebut. Hal ini disebabkan peralihan status menuntut syarat yang besar, diantaranya peningkatan jumlah mahasiswa, komposisi rasional dosen pengajar, bertambahnya kuantitas sarana dan prasarana, raihan akreditasi program studi, sebagaimana dipersyaratkan dalam peraturan yang berlaku².

Menurut Rektor IAIN Jember Babun Suharto, pada tahun 2019 ini sedang berkompetisi enam PTKIN yang diundang oleh Dirjen Pendidikan Tinggi Keagamaan Islam untuk memenuhi persyaratan alih status dari IAIN menjadi UIN. Hal ini sesuai dengan target Kementerian Agama Republik Indonesia bahwa pada tahun 2024 agar terwujud 30 UIN di Indonesia dari 17 UIN yang tercatat hingga Oktober 2019. Keenam IAIN yang sedang berjuang untuk alih status adalah IAIN Palangkaraya, IAIN Jember, IAIN Tulungagung, IAIN Purwokerto,IAIN Padangsidimpuan, dan IAIN Bengkulu. Dalam penilaian, IAIN Jember menempati peringkat pertama ${ }^{3}$.

Kedua, penamaan UIN KHAS Jember ${ }^{4}$ ditawarkan sebagai identitas yang dapat mewakili wajah kampus IAIN Jember pasca berubah status. Menurut Ketua

Tim Penyusun Naskah Akademik Pengusulan Nama UIN KHAS, AbdulHalim Soebahar, pengusulan nama KHAS menjadi penting dan strategis sebagai ke-KHAS-an UIN Jember. Salah satu alasannya dinyatakan bahwaKHAS adalah pendiri IAIN Jember. Selain itu,KHAS yang pernah

Oktober 2019. Selanjutnya, dalam penelitian ini, nama Kyai Haji Ahmad Shiddiq ditulis atau disingkat dengan kata KHAS.

2 Periksa pada Peraturan Menteri Agama RI Nomor 15 Tahun 2014 tentang Perubahan Bentuk Perguruan Tinggi Keagamaan.

${ }_{3}^{3}$ Periksa pada berita Jawa Pos Radar Jember Online Edisi 16 Mei 2019 pada laman resmi https://radarjember.jawapos.com/2019/05/16/usul-jadi-uin-kh-achmadshiddiq/, diakses pada 22 Oktober 2019.

${ }^{4}$ Dalam penulisan artikel ini, nama Universitas Islam Negeri Kyai Haji Ahmad Shiddiq Jember disingkat oleh dengan UIN KHAS Jember untuk penyebutan yanglebih familiar dan popular. Menurut hemat penulis, singkatan itu juga menjadi simbol yang mudah diingat sebagaimana penamaan (naming) UIN Sunan Kalijaga dengan UIN Suka, UIN Sunan Ampel Surabaya dengan

UINSA, UIN Maulana Malik Ibrahim dengan UIN Maliki, UIN Sunan Gunung Djati Bandung dengan UIN SGD, dan sebagainya. 
menjadi Rais 'Aam PBNU tidak hanya milik Nahdlatul Ulama, tetapi menjadi milik bersama bangsa Indonesia. Sebab, pemikirannya tentang keislaman dan kebangsaan banyak menjadi rujukan para tokoh bangsa dan banyak menginspirasi generasi bangsa, dan masih relevan hingga saat ini ${ }^{5}$.

Alasan kedua ini menjadi fokus peneliti untuk menelusuri lebih mendalam mengenai perspektif KHAS terhadap realitas dinamika ulama dan dinamisasi pondok pesantren di Indonesia. Perspektif orisinil KHAS yang diteliti salah satunya ditampilkan dalam Majalah Pesantren Edisi No. 4/ Vol. II/1985.Pemilihan majalah tempo dulu ini didasarkan pada beberapa pertimbangan. Pertama, menggali makna penting dari opini yang digagas KHAS sebagai khazanah bagi inspirasi pengembangan model komunikasi pesantren ${ }^{6}$ di masa-masa mendatang seiring dengan perubahan status UIN KHAS Jember. Artikel berjudul "Dari Kitab Kuning Sampai Kontak Masyarakat" yang ditulis KHAS pada halaman 51-53 ini menjelaskan tentang pesan penting atas makna ulama, kyai, dan dinamisasi pesantren. Identitas yang ditulis oleh KHAS adalah Rois 'Am Syuriyah PB. NU.

Pandangan orisinil-klasik KHAS ini, menurut peneliti, memiliki relevansi dengan semangat visi IAIN Jember", yakni "Pusat Kajian dan Pengembangan Islam Nusantara" dan misi IAIN Jember yang menyelenggarakan penelitian untuk mengembangkan aspek keilmuan dan keislaman berbasis pesantren. Dalam rangka memperkuat identitas Islam di Nusantaratersebut, pemikiran-pemikiran para ulama pesantren, diantaranya opini yang ditulis oleh KHAS itu menjadi wawasan mendalam dalam melahirkan pemahaman yang jernih relasi antara pesantren dengan

${ }^{5}$ Periksa berita lengkapnya pada media online Arrahmah pada lamanhttps:/ / www.arrahmah.co.id/2019/06/34696/kh-ahmad-siddiq-sosok-yangmenginspirasi-uin-khas-jember.html, diakses 22 Oktober 2019.

6 Penulis mengenalkan bidang kajian baru komunikasi pesantren dalam tulisan di media massa Jawa Pos Radar Jember Periksa pada web Edisi Jumat 24 Mei 2019, dan dimuat dalam laman resmi

https:/ / radarjember.jawapos.com/2019/05/23/memaknai-komunikasipesantren. Selain itu, penulis mempresentasikan artikel berjudul "Wacana Komunikasi Pesantren" dalam Seminar Internasional bertema pada Pascsarjana 2019, pada 7 September 2019. Bidang kajian komunikasi pesantren memfokuskan pada pemaknaan simbol-simbol yang terkait dengan dunia pesantren, baik yang terkait dengan aktivitas komunikasi kyai (communicator), komunikasi santri (communicant), pesan-pesan komunikasi (messages) yang berlangsung di pondok pesantren, media peribadahanmelalui masjid/ madrasah/sekolah(channel), dan pesan dalam pembelajaran kitab kuning untuk perubahan masyarakat (effect).

7 Periksa STATUTA IAIN Jember berdasarkan Keputusan Menteri Agama Nomor 15 Tahun 2016. Dalam pasal 3 disebutkan tentang visi IAIN Jember sebagai "Pusat kajian dan pengembangan Islam Nusantara". 
kampus saat berubah status menjadi UIN KHAS Jember nantinya.

Pada sisi yang lain, penelitian tentang KHAS sudah banyak ditulis dalam karya ilmiah kampus, mulai dari jenjang S1, S2, dan S3. Bahkan, biografi KHAS dengan mudah diakses melalui website. Diantaranya, dengan menelusuri melalui mesin pencari informasi Google Search dan menulis "kata kyai haji ahmad shiddiq" akan mudah dilacak sumbersumber yang otentik untuk membaca kisah hidup (otobiografi) kehidupan KHAS. Diantaranya, website resmi NU Online bisa diakses melalui laman http:/ / nahdlatululama.id/blog/2016/06/06/ riwayat-hidup-kh-achmadshiddiq/yang memuat tentang "Riwayat Hidup KH Achmad Shiddiq", http://digilib.uin-suka.ac.id/4149/ yang memuat skripsi pemikiran kebangsaan KH Ahmad Shiddiq,media massa online Republika juga pernah menurunkan tiga tulisan dengan judul "KH Achmad Shiddiq, Pimpinan NU dari Jember" selama tiga edisi yang dapat diakses melalui https://www.republika.co.id/berita/dunia-islam/khazanah/13/01/11/ mggpri-kh-achmad-shiddiq-pimpinan-nu-dari-jember-3habis, atau dapat menelusuri hasil disertasi yang ditulis oleh Dr. Syamsun Ni'am, M.Ag yang sudah dibukukan dengan judul "The Wisdom of K.H. Achmad Siddiq" dan diterbitkan Erlangga (2008) ${ }^{8}$.

Kedua, tema Majalah Pesantren edisiEdisi No. 4/ Vol. II/1985 ini menarik diangkat terkait dengan ulama, kyai, dan perubahan pesantren sebagai perbandingan dengan perkembangan kredibilitas ulama, identitas kyai, dan dinamisasi pada era kekinian. Wacana yang dibangun dalam edisi ini adalah berasal dari tokoh-tokoh penting yang memiliki kompetensi, diantaranya M Quraish Shihab, M. Dawam Rahardjo, Saifudin Zuhri, KHAS, Prof. Dr. Harun Nasution, Karel A. Steenbrink, dan Mastuhu. Perspektif kritis para cendekiawan/ intelektual muslim itu terangkum dalam wacana teks yang diusung dalam tema majalah bersampul biru dengan judul "Ramai-Ramai Menggugat Ulama" disertai dua judul pendukung, yakni "Kyai dalam Perubahan Sosial" dan "Dari Ulama ke Intelektual".

Ketiga, mengambil inspirasi pengelolaan komunikasi massa dengan berbasis perspektif media pesantren. Media Pesantren diterbitkan sebagai media informasi dan komunikasi serta wadah pengajian untuk membangkitkan kepedulian dan wawasan pengembangan melalui jalur

${ }^{8}$ Kisah biografi KHAS yang banyak ditulis secara ilmiahmenjadi alasan penulis untuk melihat sisi lain dari perspektif KHAS dalam mewacanakan ulama, kyai, dan pesantren. Dalam aspek ini, khazanah pemikiran KHAS akan terus menjadi kajian yang menarik. 
pemikiran yang bertolak pada titik pandang keagamaan ${ }^{9}$.Majalah Pesantren diterbitkan oleh Perhimpunan Pengembangan Pesantren dan Masyarakat (P3M) dengan Rekomendasi Departemen Agama No. D. III/5/BA.01/4876/84 dengan ISSN 0126-7778. Sedangkan P3M didirikan tanggal 18 Mei 1983 di Jakarta oleh sejumlah pengasuh pondok pesantren dengan dukungan beberapa pimpinan lembaga studi dan pengambangan masyarakat ${ }^{10}$.

Menurut Stanley J. Baran, komunikasi massa (mass communication) merupakan proses menciptakan kesamaan arti antara media massa dan khalayak mereka ${ }^{11}$. Salah satu bentuk produk komunikasi massa adalah majalah yang memproduksi berita dan opini untuk disebarluaskan kepada khalayak agar sasaran (komunikan) yang membaca memiliki kesamaan arti/ makna atas realitas tesk yang ditulis. Dalam hal ini, Majalah Pesantren merupakan produk komunikasi massa yang menampilkan opini tentang dunia pesantren agar arti atau makna tentang dunia pesantren dapat dipahami oleh khalayakpembacanya.

\section{Metode Kajian}

Pendekatan dalam kajian ini adalah kualitatif deskriptif dengan menggunakan studi pustaka (literature study) yang memfokuskan pada dua dimensi penting. Pertama, mendeskripsikan wacana yang dikonstruksikan Majalah Pesantren Edisi No. 4/ Vol. II/1985 opini yang ditulis oleh tokoh nasionalberpengaruhyang memiliki keterkaitan tema mengenai ulama, kyai, dan pesantren. Hal ini untuk mendukung wacana penting yang ditawarkan majalah tersebut. Dalam hal ini, peneliti juga mendukung dengan literatur lainnya yang terkait dengan pandangan KHAS melalui produk komunikasi massa, yakni media massa (media cetak, media elektronik, dan media online) dan buku.

Kedua, memaknai teksyang ditulis KHAS melalui pemaknaan bahasa kritis (critical linguistik) sehingga kata-kata tidak hanya menampilkan

${ }^{9}$ Dalam keterangan redaksinya, disebutkan "Berkala Kajian dan Pengembangan" menyajikan tulisan-tulisan ilmiah popular hasil penelitian, survei, hipotetsis atau gagasan kreatif yang menyangkut aspek pendidikan, pengembangan masyarakat, kepesantrenan, ilmu-ilmu keagamaan, dan yang semisal. Periksa Kolom sampul dalam redaksi Majalah Pesantren Edisi No. 4/ Vol.II/ 1985.

10 Disebutkan dalam Majalah Pesantren Edisi No. 4/ Vol.II/ 1985, P3M merupakan forum komunikasi, konsultasi, dan kerjasama antar pesantren, dalam usaha mengembangkan diri dan masyarakat lingkungannya.

11Stanley J. Baran, Pengantar Komunikasi Massa, Buku Jili 1 (Jakarta: Salemba Humanika, 2011), 7. 
makna yang tertulis sebagai kalimat. Tetapi, makna ${ }^{12}$ dibalik penulisan tersebut dilihat sebagai sikap kritis KHAS atas realitas yang disikapi dan tawaran tindakan perubahan sosial yang dilakukan pondok pesantren di masa-masa mendatang.Dalam hal ini, penelitimengaitkan dengan wacana dalam artikel-artikel pembanding dari penulis lain yang dipilih dewan redaksi Majalah Pesantren Edisi No. 4/Vol. II/ 198513.

Menurut Halim ${ }^{14}$ wacana bisa diartikan sebagai rangkaian linguistik yang memuat konstruksi realitas dengan sistem tanda, guna memerankan kegiatan, pandangan, dan identitas, sebagai cerminan kepentingan ideologi, politik, ekonomi, dan sebagainya. Batasan ini dihubungkan dengan konteks yang berkembang di tengah masyarakat, yang semakin nyata diartikan sebagai pernyataan kepentingan tertentu.

Dalam kajian ini, subyek penelitian adalah Majalah Pesantren Edisi No. 4/ Vol. II/ 1985 yang membicarakan mengenai wacana ${ }^{15}$ tentang menggugat posisi ulama, kyai pesantren dalam perubahan sosial, dan fenomena ulama dan intelektual. Sedangkan objek penelitiannya adalah artikel opini yang ditulis oleh KHAS berjudul “Dari Kitab Kuning sampai Kontak Masyarakat" yang membicarakan relasi ulama, kyai, dan dinamisasi pesantren.Salah satu tampilan tulisan KHAS yang diteliti adalah sebagai berikut:

${ }^{12}$ Menurut Mulyana makna muncul dari hubungan khusus antara kata (sebagai simbol verbal) dan manusia. Makna tidak melekat pada kata-kata, namun kata-kata membangkitkan makna dalam pikiran orang. Periksa Deddy Mulyana, Ilmu Komunikasi Massa: Suatu Pengantar(Bandung: Rosdakarya, 2014), 281.

13 Dewan redaksi dalam Majalah Pesantren Edisi No. 4/ Vol.II/ 1985 adalah Abdurrahman Wahid, Abdullah Syarwani, Adi Sasono, M. Dawam Rahardjo, Djohan Effendi, Said Budairy Wirosardjono, Zamakhsyari Dhofier, Musfihin Dahlan. Dijelasakan dalam boks redaksinya, pemimpin umum dipegang oleh K.H. Sahal Mahfudz dan pemimpin redaksinya M. Nasihin Hasan.

14 Syaiful Halim, Postkomodifikasi Media (Yogyakarta. Jalasutra, 2013), 85.

15 Wacana (discourse) merupakan pesan (message) yang memuat realitas yang telah dikonstruksikan dengan sistem tanda (system of sign) sebagai alat utamanya. Dalam pengertian, terdapat dua hal penting: 1) pesan itu bukanlah sususan tanda yang kosong melainkan berisi pilihan fakta; dan 2) penggunaan sistem tanda (bahasa) dalam pesan tidaklah bersifat arbitrer (sembarang) melainkan berdasarkan pilihan sadar atas dasar alasan-alasan yang jelas. Periksa Ibnu Hamad, Komunikasi sebagai Wacana (Jakarta: La Tofi Enterprises, 2010), 39. 


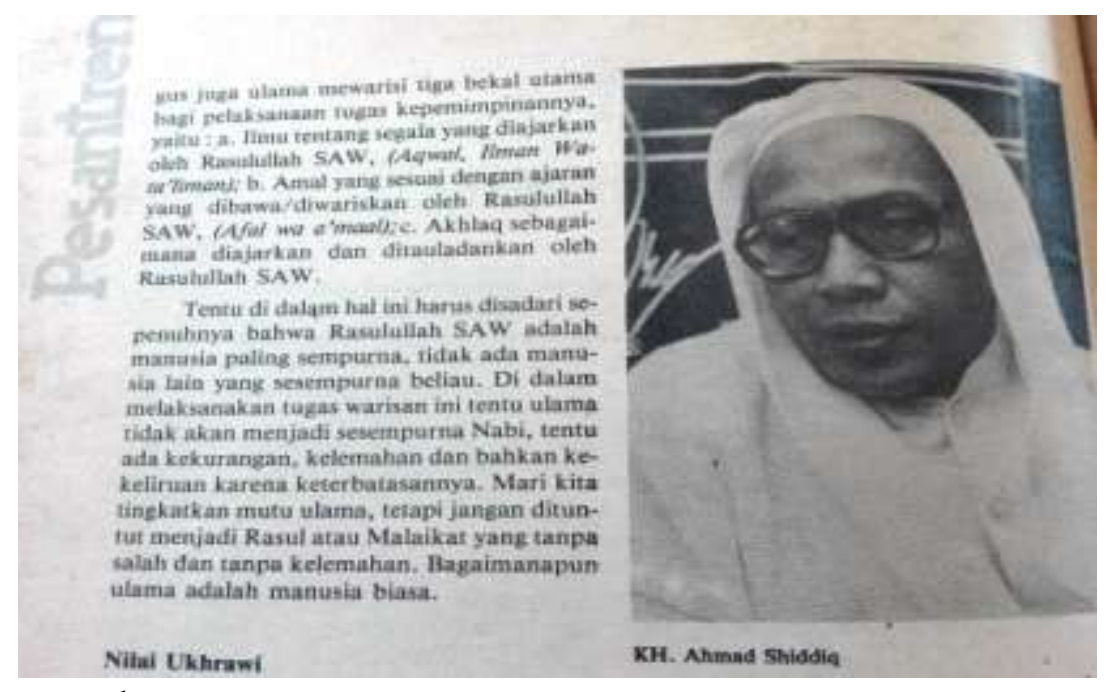

Foto: kun wazis

\section{Gambar 1.1}

Foto KHAS dalam tampilan tulisan pada Majalah Pesantren Edisi No. 4/ Vol. II/ 1985 pada halaman 52.

\section{Konstruksi Ulama Perspektif KHAS}

Perspektif KHAS memaknai ulama sebagai pewaris Nabi (al-ulama waratsat al anbiya)sebagaimana disebutkan Rasulullah SAW. Menurut KHAS, yang dapat diwarisi oleh ulama ialah apa yang diwariskan oleh Nabi dan tugas yang diemban adalah membimbing umat manusia ke jalan Allah (dakwah). Sebagaimana yang ditulis oleh KHAS sebagai berikut ${ }^{16}$ :

“Katakanlah ulama mewakili tugas kepemimpinan ummat, ummat muslim dan ummat manusia seluruhnya. Sekaligus, juga ulama mewarisi tiga bekal utama bagi pelaksanaan tugas kepemimpinannya, yaitu: a. Ilmu tentang segala hal yang diajarkan oleh Rasulullah SAW, (Aqwal, Ilman Wata'liman); b. Amal yang sesuai dengan ajaran yang dibawa/ diwariskan oleh Rasulullah SAW, (Afal wa a'maal); c. Akhlaq sebagaimana diajarkan dan ditauladankan oleh Rasulullah SAW."

Perspektif KHAS yang lebih kritis adalah wacana tentang ulama suu' yang ditampilkan pada halaman 52 dalam sub judul "Nilai Ukhrawi" melalui deskripsi yang tegas. Ditulis oleh KHAS bahwa ulama suu' adalah

${ }^{16} \mathrm{KH}$ Ahmad Shiddiq, Dari Kitab Kuning sampai Kontak Masyarakat (Jakarta: Majalah Pesantren, 1985), 51-52. Ejaan yang dipilih oleh peneliti mengikuti kata yang tertulis dalam Majalah Pesantren, yakni KH Ahmad Shiddiq. Sebab, berdasarkan penelusuran peneliti, ejaannya beragam, diantaranya seperti $\mathrm{KH}$. Achmad Siddiq, $\mathrm{KH}$. Ahmad Siddiq, dan KH. Achmad Shiddiq. 
kritik Imam Ghazali terhadap orang yang sudah dianggap ulama tetapi menyeleweng dari garis keulamaan. Ulama suu' adalah ulama yang 'memperalat ilmu agamanya' (dalam arti menyimpangkan kebenaran) untuk kepentingan duniawi yang dicarinya. Pandangan Imam Ghazali yang mengkritik fenomena ulama suu itu, menurut KHAS, kemungkinan dipengaruhi oleh kenyataan banyaknya ulama yang "digarap" oleh para penguasa di zamannya, sehingga banyak yang menyimpang dari kebenaran. KHAS menyatakan pandangan Imam al-Ghazali sebagai berikut:

"Menurutnya, sebutan ulama suu' yang artinya ulama busuk atau ulama jahat, cukup mencerminkan betapa keras kritik beliau terhadap mereka. Maksud beliau tentu untuk menyelematkan ulama/ institusi keulamaan dari rongrongan kepentingan pribadi dan kepentingan keduniaan".

Dalam konteks relasi kuasa, KHAS menegaskan bahwa hubungan yang sangat ideal antara ulama dan umaro haruslah bersifat saling mengisi untuk kesejahteraan masyarakat yang menjadi tanggungjawab keduanya bersama-sama. Ulama punya kewibawaan alamiah, sedang umaro punya kewibawaan berdasar jabatan. Dalam opini ini, KHAS mengingatkan dengan diksi yang tegas dengan "kata-kata memperingatkan dengan keras" karena kemungkinan munculnya ulama suu' sebagaimana dinyatakan berikut:

\begin{abstract}
“Ulama mengemban tugas dan tanggungjawabnya semata-mata karena panggilan Allah SWT dan tidak ada instansi yang mengawasinya selain Allah SWT sendiri, sedangkan gangguan dan godaan di dalam melaksanakan tugas sama saja dengan profesi lainnya. Oleh karena itu, ulama harus selalu berhati-hati, jangan terjerumus menjadi ulama suu'. Merk masih tetap ulama, tetapi arah perjalanan sudah menyimpang. Nauudzubillah!"
\end{abstract}

Fenomena ulama suu' ini juga ditegaskan oleh Quraish Shihab dalam artikelnya berjudul "Ulama Pewaris Nabi" yang ditampilkan dalam Majalah Pesantren Edisi No. 4/ Vol. II/ 1985, halaman 3-8 dengan mengutip pendapat Imam al-Ghazali yang membagi ulama menjadi dua katagori, yakni ulama akhirat dan ulama dunia (ulama suu'). Disebutkan, salah satu tanda seorang ulama dunia (ulama suu') adalah kunjungannya kepada penguasa.

Menurut Qurais Shibah, pendapat al-Ghazali ini tentu tidak harus 
diterima begitu saja. Perlu kiranya ditinjau bagaimana latar belakang politik dan kondisi sosial pada masyarakat sehingga beliau melontarkanpendapat tersebut. Jika hal ini jelas; maka tidak sepatutnya setiap ulama yang mempunyai hubungan baik dengan pemerintah dapat dikatagorikan sebagai ulama suu'; karena dapat saja hubungan itu merupakan suatu kewajiban dalam rangka menjaga kemaslahatan umat dan agama.

\section{Identitas Kyai Menurut KHAS}

Perspektif KHAS tentang kyai diawali dengan makna kyai yang bisa saja disematkan kepada sesuatu yang memiliki kekuatan. Dengan demikian, kyai tidak mesti dikontekkan pada manusia saja, tetapi dapat dilekatkan kepada benda-benda yang dipandang memiliki kekuatan. Sebagaimana dinyatakan KHAS sebagai berikut:

"Kyai (bisa kiai atau kyai) dalam bahasa Jawa mengandung pengertian "yang dihormati". Benda-benda yang dihormati (kramat?) di kalangan keraton Jawa disebut "kyai". Keris, kereta, lampu, dan bahkan kerbaupun (kalau tergolong yang terhormat) disebut kyai (seperti kyai Slamet, dari kraton Surakarta). Di sini nampak lebih diperlukan disiplin istilah untuk masing-masing masing-masing bidang."

Menurut KHAS, di daerah lain seorang ulama juga diberi gelar, seperti ajengan dan sebagainya. Namun ternyata yang kemudian lazim dipasang pada nama seseorang hanya gelar kyai ${ }^{17}$. Ulama dari Pasundan pun disebutnya dengan kyai yang disingkat "K". KHAS memberikan contoh, yakni KH Ilyas Ruchiyat, bukan A (jengan) Ilyas Ruchiyat.

Pandangan KHAS tentang istilah kyai ini senada dengan tulisan Saifuddin Zuhri berjudul "Kyai, Profil Ulama Indonesia" yang dimuat Majalah Pesantren No. 4/ Vol. II/ 1985 halaman 45. Dinyatakan bahwa di Jawa Tengah dan Jawa Timur panggilan kyai ditujukan kepada ulama misalnya, Kyai Haji Raden As'ad Samsul Arifin, Kyai Haji Ali Maksum dan sebagainya. Masyarakat Jawa Barat menggunakan sebutan ajengan, adapun masyarakat Jakarta (Betawi) memakai sebutan tuan guru. Tetapi waktu sekarang, sebutan kyai sudah membudaya di kedua daerah tersebut.

Menurut Saifudin Zuhri, pada zaman Kerajaan Islam Demak (1478-

${ }^{17}$ Fenomen kyai dapat dilacak dari sejarah perjalanan dan perkembangan pesantren di nusantara. Sejak awal perkembangannya di Indonesia, pesantrenpesantren menjadi sangat populer di masyarakat terutama karena ada sosok kiai yang diakui memiliki keahlian khusus dalam sesuatu bidang ilmu. Periksa Asep Saeful Muhtadi, Ranting-Ranting Dari Tepi Pesantren (Bandung: Insan Komunika, 2012), 8-9. 
1547 M) disambung dengan Kerajaan Pajang (1547-1586 M) sebutan kyai bagi para ulama tidak berjalan. Para ulama yang dimasyurkan sebagai muballigh Islam yang mendampingi Sultan lazimnya disebut Wali atau Waliyullah. Saifudin Zuhri menukil pendapat Syekh Yusuf bin Isma'il alNabhani menjelaskan arti wali atau waliyullah: Man tawaalat thoo'atuhu min ghairi takhollihi ma'shiyatin, Orang yang secara terus menerus menjalani taat kepada Allah SWT tanpa diselingi perbuatan dosa (Jami' Karamat alAuliyaa).

Pada zaman tersebut para ulama itu dipanggil dengan sebutan Sunan, sebagaimana kita jumpai dalam sejarah Wali Songo yang termasyur seperti Sunan Ampel, Sunan Giri, Sunan Bonang,Sunan Kalijogo, Sunan Kudus dan sebagainya. Juga bagi generasi penerus mereka seperti Sunan Ngudung, Sunan Tembayat, Sunan Geseng dan lain sebagainya.

Menurut KHAS, dengan disiplin yang jelas mengenai kekuatan kyai dalam melakukan perubahan melalui pondok pesantren dengan mendasarkan pada ilmu agama Islam, posisi kyai dan ulama simetris.Melalui bahasa yang lugas dan tegas, KHAS menegaskan, secara istilah, kyai dapat disamakan dengan ulama. Kyai adalah gelar yang diberikan kepada individu yang sudah masuk katagori ulama.

Pandangan KHAS diperkuat dengan pendapat Mastuhu dalam Majalah Pesantren halaman 38-49 melalui artikelnya berjudul "Pesantren dan Ulama Masa Depan" menekankan relasi yang kuat mengenai identitas kyai dan ulama. Hal ini dapat dimaknai dari pernyataan Mastuhu sebagai berikut:

“....esensi pesantren tetap tidak berubah, yaitu adanya perangkat: ulama/ kyai lengkap dengan kharismanya, santri, masjid/ surau, pondok, kitab, sistem yang kolektif, integrasi penuh dengan masyarakat pendukungnya, dan memandang kehidupan sebagai peribadatan,"

Mastuhu dalam wacana yang dinarasikannya menyatakan identitas tidak akan berubah dalam merespon tantangan globalisasi selama pondok pesantren ${ }^{18}$ berada dalam esensinya, yang salah satunya disebut "ulama/

18Zamakhsyari Dhofier memberikan batasan mengenai sebuah institusi yang layak disebut pondok pesantren. Menurutnya, pondok, masjid, santri, pengajaran kitab Islam klasik dan kyai adalah lima elemen dasar tradisi pesantren. Ini berarti bahwa suatu lembaga pengajian yang telah berkembang hingga memiliki kelima elemen tersebut berubah statusnya menjadi pesantren. Periksa Zamakhsyari Dhofier, Tradisi Pesantren: Studi Tentang Pandangan Hidup Kyai (Jakarta: LP3ES, 2011), 79-93. 
kyai dengan kharismanya".

\section{Dinamisasi Pesantren Pandangan KHAS}

Perspektif KHASmemandang pondok pesantren harus terus berdinamika. Untuk itu, KHAS berhati-hati dalam menggunakan istilah perkembangan pesantren dengan memilih kata "dinamisasi" bukan modernisasi karena pesantren akan berdialektika dengan perkembangan zaman yang bentuk tantangannya beragam. Sedangkan makna modernisasi dalam konteks saat itu memiliki kecenderungan kepada westernisasi yang mengarah pada imitasi budaya barat yang tidak sejalan dengan budaya pondok pesantren. Kehatian-hatian KHAS dalam memilih kata yang tepat untuk menggambarkan realitas menunjukkan sikap arif dalam memahami problematika zaman.

Menurut KHAS, di Indonesia, belum ada sistem pendidikan lain yang mampu mendorong munculnya ulama selain sistem pendidikan pesantren. Hal ini disebabkan di dalam pesantren (yang lengkap) terdapat faktorfaktor yang sangat mempengaruhi pertumbuhan siswa (santri) seutuhnya menjadi calon ulama, yaitu:a.Lingkungan dan suasana keagamaan yang mendalam; b.Ketauladanan kyai pengasuh yang berkesan; c.Pelajaran ilmu keagamaan yang intensif; d.Kesederhanaan, kemandirian dan kebersamaan; dan e.Tidak ada orientasi kepada formalistik.

Dalam pandangan KHAS, bisa saja ada lembaga pendidikan lain yangakan berhasil mendorong tumbuhnya calon ulama, asal memenuhi lima faktor esensial tersebut. Sebaliknya, meskipun disebut pesantren, kalau tidak ada aspek/ faktor esensial, maka akan sulit menghasilkan calon ulama. Menurutnya, pembenahan pesantren ${ }^{19}$ harus dilakukan karena tuntunan zaman, namun faktor-faktor esensialnya harus tetap ada.

Menurut KHAS, pesantren bolehmengadakan madrasah, tetapi madrasah itu harus hanya merupakan salah satu sub-sistem dari

${ }^{19}$ Menurut Nahrawi, akselerasi dan dinamika penyebaran ajaran agama Islam dapat berjalan di pondok pesantren disebabkan tiga hal. Pertama, metode dakwah mudah dimengerti oleh semua lapisan masyarakat, dapat diamalkan secara luwes, ringan, dan memberikan nuansa religius terutama ketika masyarakat sekitar pesantren sering mendengar para santri melafalkan bacaan dan puji-pujian. Kedua, para ulama dapat menyampaikan ajaran Islam sesuai dengan keadaan dan situasi saat itu, tidak mencela, menolak, tidak merendahkan kepercayaan, dan norma-norma yang telah ada sebelumnya dianut masyarakat setempat. Ketiga, ulama tidak mengalami hambatan yang berarti dalam masalah sandang dan papan, karena kesuburan tanah ikut berperan penting dalam kehidupan masyarakat. Periksa Amirudin Nahrawi, Pembaharuan Pendidikan Pesantren (Yogyakarta: Gama Media, 2008), 3. 
keseluruhan sistem pesantren, jangan menjadi sesuatu yang berdiri sendiri terlepas dari sistem. Secara kritis, KHAS mengingatkan suatu fenomena apabila suatu madrasah tidak terkait dengan sistem pendidikan di pesantren dengan menyatakan sebagai berikut:

"Kalau madrasah sudah terlepas dari sistem pendidikan pesantren meskipun secara fisik berada di dalam pesantren, maka madrasah itu akan sama saja dengan madrasah/ sekolah di luar pesantren, bahkan mungkin dapat membawa" penyakit dari luar ke dalam pesantren".

Pesan komunikasi kritis yang dapat dimaknai dari pernyataan KHAS adalah "penyakit dari luar ke dalam pesantren" merupakan diksi yang nyata bahwa sistem yang dibangun pesantren memiliki pengaruh yang kuat dalam membentuk identitas suatu madrasah yang berbasis pendidikan pesantren.

Menurut KHAS, pembenahan pesantren dalam wujud dinamisasi, sudah banyak dilakukan oleh berbagai lembaga, bahkan lembaga non pesantren. Sampai batas-batas tertentu, usaha itu sangat bagus.Pembenahan itu harus juga ditujukan untuk memulihkan unsur-unsur positifpesantrenyang tampak mulai ditinggalkan seperti pengajian kitab kuning, pelajaran tatabahasa Arab (Qowa'id = Nahwu, Sharf, Balaghah), diskusi ilmiah diniyah (muhabatsah masa-il).

Masalah pelayanan kepada masyarakat oleh pesantren yang menurut KHAS lebih keren disebut pengabdian dan pengembangan masyarakatsangat menarik perhatian banyak pihak. Posisi seorang kyai pengasuh pesantren bukan saja tokoh pusat pesantren, tetapi juga bagi masyarakat sekitarnya ${ }^{20}$.Oleh karena itu, pesantren harus pula dapat menjadi pusat beberapa kegiatan masyarakat. Untuk itu, pesantren perlu punya program "kontak dengan masyarakat" dalam wujud yang bermanfaat bagi semua pihak. KHAS mencontohkan program pengabdian dan pengembangan masyarakat oleh pesantren yang menyentuh langsung kepada masyarakat sebagai berikut:

“Di daerah Jember umpamanya, ada pesantren (sejak dahulu) yang

${ }^{20}$ Menurut Imam Suprayogo, dalam waktu sekian lama dalam kehidupan seharihari kyai tinggal di pesantren bersama para santrinya. Peran kyai dalam pesantren begitu luas dan utuh, ia tidak saja memerankan diri sebagai guru, melainkan juga pengasuh dan bahkan menjadi pengganti orang tua para santri. Pelayanan kyai terhadap santrinya bisa dikatakan selama 24 jam, mulai dari membangunkan tidur para santri, mengajari membaca kitab, berinteraksi dengan lingkungannya, dan memimpin kegiatan spiritual. Periksa Imam Suprayogo, Kyai dan Politik (Malang: UIN Malang Press, 2009), 123. 
pada saat petani sibuk mengerjakan/ mengurus sawah, kyai tidak mengajar di waktu siang, hanya malam saja. Semua santri pada siang hari disebar/ diperbantukan kepada para petani untuk ikut menggarap sawah. Betulbetul program terpadu untuk memasyarakatkan pesantren dan mempesantrenkan masyarakat".

Diksi yang dipilih oleh KHAS dalam menutup wacana artikelnya adalah dengan menekankan pentingnya pemberdayaan pesantren di masamasa mendatang. Pesan komunikasinya, semua pihak memiliki kontribusi peran dalam pemberdayaan pesantren, tidak hanya terbatas pada kyai, ustad, santri, dan wali santri, tetapi masyarakat umum dan negara harus hadir dalam menjaga identitas pesantren ini. Hal ini dapat disimak dari paragraf akhir kalimat yang dipilih KHAS sebagai berikut:

"Namun, bagaimanapun, pembenahan dalam arti pemulihan pesantren sangat perlu, di samping pembenahan dalam arti pengembangan. Justru pada saat-saat sekarang ini dua jenis pembenahan itu dilaksanakan secara berbarengan".

Pembenahan pesantren dalam perspektif KHAS ini sekaligus menjadi tantangan semua pihak dalam merespon dinamika kehidupan masyarakat pondok pesantren di Indonesia yang berjumlah 28.194 dengan 4.290.626 santri sebagaimana data Kementerian Agama Republika Indonesia pada tahun 2016. ${ }^{21}$ Sumber daya pesantren yang sedemikian besar akan terus memiliki kekuatan unggul dalam membentuk karakter bangsa Indonesia.

\section{Penutup}

Berdasarkan studi literatur dengan memfokuskan pada analisis wacana bahasa komunikasi yang ditulis oleh KHAS, dapat disimpulkan wacanawacana penting yang dapat memberikan kontribusi dalam membangun visi besar UIN KHAS Jember dimasa-masa mendatang,diantaranya sebagai berikut:

1. Perspektif KHAS menyatakan bahwa ulama merupakan pewaris Nabi dalam melaksanakan tugas membimbing umat manusia ke jalan Allah (dakwah). Ulama juga mewarisi tiga bekal utama bagipelaksanaan tugas kepemimpinannya, yakni ilmu, amal, dan akhlaq yang telah diajarkan Rasulullah SAW.

2. Perspektif KHAS menyatakan bahwa kyai dapat dikategorikan sebagai ulama karena kepemimpinan kyai yang terus berusaha melaksanakan

${ }^{21}$ Republika, Tajuk: Regulasi Baru Pendirian Ponpes (Jakarta: Koran Republika Edisi Jumat, 2 Maret 2018. Kolom opini), 6. 
ilmu, amal, dan akhlaq yang diperintahkan Rasulullah SAW. Kyai adalah gelar yang diberikan kepada individu yang masuk kategori ulama.

3. Perspektif KHAS menyatakan bahwa ulama/ kyai harus senantiasa berhati-hati agar tidak sampai terjerumus menjadi ulama suu' (ulama busuk, ulama jahat), yakni ulama/ kyai yang memperalat ilmu agamanya, dalam arti menyimpang untuk kepentingan duniawi yang dicarinya.

4. Perspektif KHAS menyatakan bahwa sistem pendidikan pesantren mampu mengantarkan santri menjadi calon ulama karena dipengaruhi faktor lingkungan dan suasana keagamaan yang mendalam, keteladanan kyai pengasuh pesantren yang berkesan, pelajaran ilmu keagamaan yang intensif, kesederhanaan, kemandirian, dan kebersamaan, serta tidak ada orientasi kepada formalitas

5. Perspektif KHAS menyatakan bahwa pesantren harus memiliki program terpadu "kontak dengan masyarakat" untuk memasyarakatkan pesantren dan mempesantrenkan masyarakat. Hal ini dapat dilakukan dapat dilakukan dengan dua pembenahan, yakni pemulihan pesantren dan pengembangan pesantren.

\section{Daftar Pustaka}

\section{Buku}

Baran, Stanley J. 2011. Pengantar Komunikasi Massa, Buku Jilid 1. Jakarta: Salemba Humanika.

Dhofier, Zamakhsyari. 2011. Tradisi Pesantren: Studi Tentang Pandangan Hidup Kyai. Jakarta: LP3ES.

Halim, Syaiful. 2013. Postkomodifikasi Media. Yogyakarta. Jalasutra.

Hamad, Ibnu. 2010. Komunikasi sebagai Wacana. Jakarta: La Tofi Enterprises.

Mastuhu. 1985. Pesantren dan Ulama Masa Depan. Artikel dalam Majalah Pesantren Edisi No. 4/ Vol. II/1985. Jakarta: Perhimpunan Pengembangan Pesantren dan Masyarakat (P3M).

Muhtadi, Asep Saeful. 2012. Ranting-Ranting Dari Tepi Pesantren. Bandung: Insan Komunika.

Nahrawi, Amiruddin. 2008. Pembaharuan Pendidikan Pesantren. Yogyakarta: Gama Media.

Mulyana, Deddy. 2014. Ilmu Komunikasi Massa: Suatu Pengantar. Bandung: Rosdakarya. 
Republika. 2018. Tajuk: Regulasi Baru Pendirian Ponpes. Koran Republika Edisi Jumat, 2 Maret 2018. Kolom opini, halaman 6.

STATUTA IAIN Jember berdasarkan Keputusan Menteri Agama Nomor 15 Tahun 2016.

Shiddiq, KH Ahmad. 1985. Dari Kitab Kuning sampai Kontak Masyarakat. Artikel dalam Majalah Pesantren Edisi No. 4/ Vol. II/1985. Jakarta: Perhimpunan Pengembangan Pesantren dan Masyarakat (P3M).

Shihab, Quraish. 1985. Ulama Pewaris Nabi. Artikel dalam Majalah Pesantren Edisi No. 4/ Vol. II/1985. Jakarta: Perhimpunan Pengembangan Pesantren dan Masyarakat (P3M).

Suprayogo, Imam. 2009. Kyai dan Politik, Malang: UIN Malang Press.

Wazis, Kun. 2019. Wacana Komunikasi Pesantren. Makalah Seminar Internasional Pascasarjana. Dipresentasikan 7 September 2019.

Zuhri, Saifuddin. 1985. Kyai, Profil Ulama Indonesia. Artikel dalam Majalah Pesantren Edisi No. 4/ Vol. II/1985. Jakarta: Perhimpunan Pengembangan Pesantren dan Masyarakat (P3M).

\section{Media Siber}

http:/ / digilib.uin-suka.ac.id/4149/

https:/ / www.arrahmah.co.id/2019/06/34696/kh-ahmad-siddiq-sosokyang-menginspirasi-uin-khas-jember.html, diakses 22 Oktober 2019 https:// radarjember.jawapos.com/2019/05/16/usul-jadi-uin-kh-achmadshiddiq/, diakses pada 22 Oktober 2019.

https:// beritajatim.com/pendidikan-kesehatan/iain-jember-

bertransformasi-jadi-uin-kh-achmad-shiddiq/, diakses 22 Oktober 2019

https://www.republika.co.id/berita/dunia-

islam/khazanah/13/01/11/mggpri-kh-achmad-shiddiq-pimpinan-

nu-dari-jember-3habis

http:/ / nahdlatululama.id/blog/2016/06/06/riwayat-hidup-kh-achmadshiddiq/

https:// www.bukukita.com/Agama/Islam/72861-The-Wisdom-of-K.H.Achmad-Siddiq-1.html

Wazis, Kun. 2019. Memaknai Komunikasi Pesantren. Koran Jawa Pos Radar Jember Edisi Jumat 24 Mei 2019, dan Jawa Pos Radar Jember Online https://radarjember.jawapos.com/2019/05/23/memaknaikomunikasi-pesantren. 
